\title{
William Webster: author of Canada's first anesthesia textbook
}

\author{
John Wade, MD, FRCPC
}

Received: 20 April 2018/Accepted: 21 April 2018/Published online: 18 May 2018

(C) Canadian Anesthesiologists' Society 2018

Born in 1865 in Manchester, England, Dr. William Webster subsequently moved to Canada, graduating from the Manitoba Medical College in 1895. He returned to England to study pathology but eventually moved back to Winnipeg to begin a general practice. In 1906, Webster became the first full-time anesthesiologist in Western Canada and was named as an "honorary anesthetist" in the Winnipeg General Hospital's Department of Surgery. ${ }^{\text {A }}$

He was a leader in anesthesia not only in Winnipeg but the rest of Canada as well. An inquisitive nature and
Figure Dr. William Webster (1865-1934) (A) authored the first Canadian textbook of anesthesia, The Science and Art of Anesthesia, the front page of which is shown in the image (B)

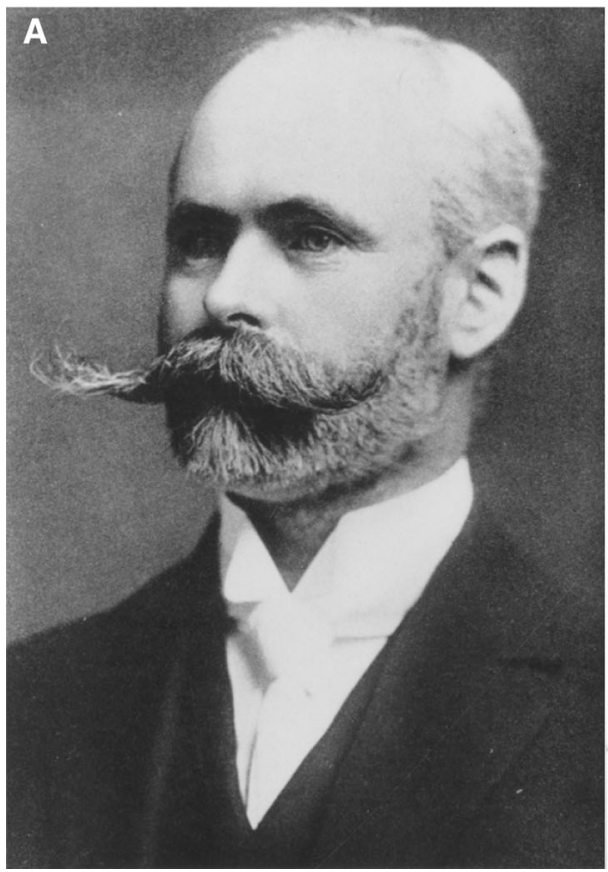

B

THE SCIENCE AND ART

OF

ANESTHESIA

COLONEI, WILLIAM WEBSTER, D.S.O., M.D., C.M.

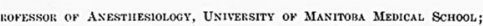

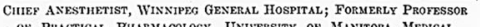

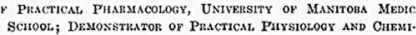
cal Physlology, Unitersity of Mantroba; Pathologist,

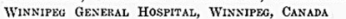

ST. LOUIS THE C. V. MOSBY COMPANY 1924

J. Wade, MD, FRCPC ( $₫)$

Department of Anesthesiology Perioperative \& Pain Medicine,

Max Rady College of Medicine, University of Manitoba,

Winnipeg, MB, Canada

e-mail: wade@mymts.net

\footnotetext{
A An autonomous Department of Anesthesia at the University of Manitoba in Winnipeg was not formed until 1967.
} 
interest in research resulted in his pioneering of many new anesthetic techniques in Western Canada. His textbook, The Science and Art of Anesthesia (Figure) was published in 1924 and remained the only Canadian textbook of anesthesia for most of that century. Webster served as a colonel in the First World War and commanded the number 4 field ambulance. He was awarded the Distinguished Service Order for his "valour under fire."

Dr. Webster's interest in motor cars (including owning one of the first cars in Manitoba) resulted in his appointment as the first President of the Manitoba Motor League. He was also an ardent sailor, tragically resulting in a boating accident that caused his death in 1934. William Webster was a true Canadian pioneer in anesthesiology.

Conflicts of interest None declared.

Editorial responsibility This submission was handled by Dr. Hilary P. Grocott, Editor-in-Chief, Canadian Journal of Anesthesia. 